\title{
Physical Characteristics of Aceh Traditional Salt and Its Potential as Raw Material for Thermal Energy Storage
}

\author{
Gunawati ${ }^{1,2}$, Syahrul Humaidi ${ }^{1}$, Adi Setiawan ${ }^{3,4^{*}}$, Makmur Sirait ${ }^{5}$, Zulkarnain Jalil ${ }^{2}$, \\ Nadilla Ramadhani ${ }^{2}$, Amar Makruf², Shafira Riskina4, Irhamni² \\ 1 Doctoral Program in Physics, Faculty of Mathematics and Natural Sciences, Universitas Sumatera Utara, \\ Padang Bulan, 20155, Medan, Indonesia \\ 2 Department of Physics, Faculty of Mathematics and Natural Sciences, Universitas Syiah Kuala, Darussalam, \\ 23111, Banda Aceh, Indonesia \\ 3 Mechanical Engineering Department, Faculty of Engineering, Universitas Malikussaleh, Bukit Indah, 24352, \\ Lhokseumawe, Indonesia \\ ${ }^{4}$ Magister Program in Renewable Engineering, Faculty of Engineering, Universitas Malikussaleh, Bukit Indah, \\ 24352, Lhokseumawe, Indonesia \\ 5 Departement of Physics, Faculty of Mathematics and Natural Science, Universitas Negeri Medan, 20221, \\ Medan, Indonesia \\ * Corresponding author's email: syahrul1@usu.ac.id
}

\begin{abstract}
Thermal energy storage is an important element in order to conserve the energy and optimize the overall efficiency. Development of energy storage system for local purposes requires some information on the raw material which is abundantly available in the local market. This study aimed to investigate the characteristics of traditionally produced salt in Aceh in terms of its potential use as a raw material for thermal energy storage. The sample was collected from the Aceh Besar District and treated by heating at temperatures of $400{ }^{\circ} \mathrm{C}$ and $800{ }^{\circ} \mathrm{C}$ in a muffle furnace. This treatment is carried out to study the changes in properties and define the best procedure for salt preparation. All samples were characterized under a number of techniques including XRF, XRD, SEM/EDS, TGA/ DSC analysis, density, thermal conductivity, and electrolytic conductivity. The XRF characterization showed that the local Aceh salt was graded as a category III salt. Furthermore, according to the TGA/DSC characterization, the melting temperature is close to $800{ }^{\circ} \mathrm{C}$, and the enthalpy value is close to $492 \mathrm{~kJ} / \mathrm{kg}$. It is ample evidence that the Aceh salt can be used as a thermal energy storage material. Furthermore, increasing the temperature of local salt's heat treatment contributes to increasing the enthalpy value, crystal size, density, thermal conductivity, and electrolyte conductivity.
\end{abstract}

Keywords: aceh salt, enthalpy, thermal conductivity, thermal energy storage.

\section{INTRODUCTION}

Increasing levels of greenhouse gas emissions and fuel prices force the attempts to use various renewable energy sources more efficiently, such as solar radiation, wind energy, and geothermal energy. One of the factors to remember when developing new and renewable energy sources is the need to develop energy storage devices. Mechanical, electrical, thermochemical, and thermal energy storage can be distinguished (Sharma et al., 2009). Thermal energy storage (TES) is a system that allows the energy demand and supply to be balanced. Thermal energy storage systems are classified into sensible heat storage and latent heat storage (Jegadheeswaran and Pohekar, 2009). The use of latent heat storage systems is an essential way of store thermal energy, for the high density and isothermal nature of the storage process (Strizhenok and Ivanov, 2021). The use 
of PCM (Mehling and Cabeza, 2008) is one of the thermal energy storage strategies.

PCM (phase change material) is a material for storing heat energy by utilizing latent heat during the phase transition at a relatively constant temperature. Latent heat storage is based on the absorption or release of heat when the storage material undergoes a phase change from solid to liquid or liquid to gas or vice versa (Anand et al., 2020).

The environmental and social impacts of the PCM-based TES are considered part of the assessment criteria, in addition to the technical aspects. Apart from its low availability and low cost, PCM is primarily defined by its thermal, physical, kinetic, and chemical properties (Sharma et al., 2009). Chloride salt is a PCM substance with high latent heat and strong heat transfer (Sharma et al., 2009). For example, $\mathrm{NaCl}$ melts at $800.7^{\circ} \mathrm{C}$ (Myers and Goswami, 2016). As reported by Nazir et al., all inorganic PCM has an energy density greater than $200 \mathrm{MJ} \cdot \mathrm{m}^{-3}$. $\mathrm{KF}, \mathrm{MgCl}_{2}$, and $\mathrm{NaCl}$ have the highest latent heat $\left(>400 \mathrm{~kJ} \cdot \mathrm{kg}^{-1}\right)$ and energy density $\left(>900 \mathrm{MJ} \cdot \mathrm{m}^{-3}\right)$ among all inorganic materials, the corresponding melting points of each are $857{ }^{\circ} \mathrm{C}$, $714{ }^{\circ} \mathrm{C}$ and $800{ }^{\circ} \mathrm{C}$ (Nazir et al., 2019) and $\mathrm{NaCl}$ has thermal conductivity of $5 \mathrm{~W} \cdot \mathrm{m}^{-1} \cdot \mathrm{K}^{-1}$ (Agyenim et al., 2010) as well as density of $2160 \mathrm{~kg} \cdot \mathrm{m}^{-3}$ (Mehling and Cabeza, 2008).

In this study, local salt was used as sample material for latent heat storage material, also known as Phase Change Material (PCM). Local salt is traditionally processed in the Aceh Besar region. Furthermore, in this study, characterization was carried out by checking through the analysis of enthalpy shifts, especially the latent heat value found in the material by using Thermo-Gravimetry Analysis-Differential Scanning Calorimetry (TGA-DSC). Quantitative and qualitative analysis of elemental content using X-Ray Fluorescence (XRF), grain size and degree of crystallinity by using X-Ray Diffraction (XRD), morphological or elemental analysis of local salt by using Scanning Electron Microscope-Energy Dispersive X-Ray (SEM-EDX), thermal conductivity analysis, density analysis and electrolyte conductivity analysis.

\section{METHODOLOGY}

\section{Sample preparation}

The substance used in this analysis is local salt $(\mathrm{NaCl})$ from the Lam Ujong Village in Aceh
Besar. The processing of salt samples starts with drying the salt in an oven at $400{ }^{\circ} \mathrm{C}$ until the water content is reduced to a fixed mass. Furthermore, heat treatment is used to modify the salt. The sample I is unheated, sample II is heated to $4000{ }^{\circ} \mathrm{C}$ with a 30 -minute hold time, and sample III is heated to $8000{ }^{\circ} \mathrm{C}$ with a 30 -minute hold time. After heating, samples II and III were allowed to self-crystallize at room temperature. Then, using a mortar and pestle, salt was ground until smooth.

\section{Characterization}

The salt was crushed and characterized using the X-Ray Fluorescence (XRF) branded Panalytical MiniPal 4 to determine the quality and percentage of elemental composition in local salt samples. Scanning Electron Microscope-Energy Dispersive X-Ray (SEM-EDS) branded Thermo Fisher Scientific type E Prism fitted with EnergyDispersive X-Ray Spectroscopy (EDS) was used for elemental and morphological analysis.

In order to identify know the crystal size, the Shimadzu XRD-D7000 machine was used, which was equipped with a Maxima X-Ray Diffractometer where X-rays are scanned continuously from an angle of 10 to 80 degrees 2-theta at a speed of 2.0 degrees per minute. The target $\mathrm{X}$-ray tube is $\mathrm{Cu}$ with a voltage of $40.0 \mathrm{kV}$ and a current of $30.0 \mathrm{~mA}$. The two samples were crushed with pestle and mortar before being placed in a stainless-steel sample holder. MATCH! is used for data analysis (peak scanning and matching) - Phase Identification from Powder Diffraction Data - Version 2.4.7. On the basis of the data obtained from XRD, the data were matched with the database and the crystal size was calculated using the Scherrer equation.

In order to analyze the value of latent heat, the TGA and DSC analyses were performed under the Mettler Toledo TGA/DSC machine with a high-temperature furnace by purging with nitrogen at a flow rate of $30 \mathrm{ml} / \mathrm{min}$ and heating rate of $15{ }^{\circ} \mathrm{C} / \mathrm{min}$. The samples were placed in an alumina crucible c.a. $10 \mathrm{mg}$, then heated from an ambient temperature to $800{ }^{\circ} \mathrm{C}$. After that, Leybold's Single Plate Method was used to determine the thermal conductivity value of the salt produced. Density analysis used the bulk density method, with a $10-\mathrm{ml}$ measuring cup and digital scales. The measurement of sample weight was carried out ten times. The 
electrolytic conductivity was obtained from the Laboratory Benchtop Meter measurement; the size of the glass used is $50 \mathrm{ml}$.

\section{RESULTS AND DISCUSSION}

\section{Analysis of the content and elemental composition}

XRF analysis is used to determine the content and percentage of elemental composition found in local salt samples. Table 1 shows the XRF analysis results for local salt originating from Aceh Besar. There are three samples, the data of which are presented in this table, that is, untreated samples, samples heated at $400{ }^{\circ} \mathrm{C}$, and samples heated at $800^{\circ} \mathrm{C}$.

The XRF analysis in Table 1 reveals that the elemental $\mathrm{Cl}$ content has higher value than other elements from local Aceh salt. From this table, there is no visible element of $\mathrm{Na}$ due to the ability of the XRF device which cannot read the presence of the Na element (Yalçin and Mutlu, 2012). The three local salt samples $(\mathrm{NaCl})$ are still in the good category since they do not have visible heavy metal contaminants. There are several contaminants of metal elements such as $\mathrm{Ca}$ and Mo, where the content of these elements is still below the threshold. In the local salt compounds $(\mathrm{NaCl})$, there are also other impurity-metal elements with a relatively small percentage.

According to Salim et al., 2016, salt with a $\mathrm{Cl}$ content of less than $94 \%$ was graded as category III quality salt (Salim and Munadi, 2016). On the basis of the $\mathrm{Cl}$ level, the local salt $(\mathrm{NaCl})$ produced traditionally has not met the salt content

Table 1. XRF analysis result

\begin{tabular}{|c|c|c|c|}
\hline \multirow{2}{*}{ Element } & \multicolumn{3}{|c|}{ Sample (\%) } \\
\cline { 2 - 4 } & $\begin{array}{c}\text { Un-treated } \\
\mathrm{NaCl}\end{array}$ & $\begin{array}{c}\text { Pre-heated at } \\
400^{\circ} \mathrm{C}\end{array}$ & $\begin{array}{c}\text { Pre-heated at } \\
800^{\circ} \mathrm{C}\end{array}$ \\
\hline $\mathrm{P}$ & 0.17 & 0.14 & 0.14 \\
\hline $\mathrm{S}$ & 0.1 & - & - \\
\hline $\mathrm{Cl}$ & 93.29 & 92.82 & 93.94 \\
\hline $\mathrm{K}$ & 0.33 & 0.43 & 0.31 \\
\hline $\mathrm{Ca}$ & 2.29 & 2.17 & 1.86 \\
\hline $\mathrm{Fe}$ & 0.11 & 0.11 & 0.066 \\
\hline $\mathrm{Cu}$ & 0.058 & 0.052 & 0.052 \\
\hline $\mathrm{Br}$ & 0.23 & 0.15 & 0.12 \\
\hline $\mathrm{Mo}$ & 2.9 & 3.37 & 3.04 \\
\hline $\mathrm{Nd}$ & 0.48 & 0.40 & 0.48 \\
\hline $\mathrm{Pr}$ & - & 0.35 & - \\
\hline
\end{tabular}

needed as the raw material for Phase Change Material (PCM). The salt $(\mathrm{NaCl})$ used for PCM is a type of industrial salt with a purity percentage $(\mathrm{NaCl})$ of greater than $99 \%$ (Tian et al., 2017). In this study, the salt $(\mathrm{NaCl})$ used with a purity level of $\mathrm{NaCl}>99 \%$. Salt $(\mathrm{NaCl})$ is mixed with salt $\left(\mathrm{CaCl}_{2}\right)$ and $\mathrm{Mg}$ particles. The result of mixing the three materials could increase the specific heat capacity value by $10 \%$ which could be used as heat storage at high temperatures. Then in another study, an investigation was carried out using salt $(\mathrm{NaCl})$ with a purity level of $\mathrm{NaCl}>99 \%$ mixed with salt $\left(\mathrm{Na}_{2} \mathrm{CO}_{3}\right)$. The mixing of the two materials shows that the salt has good thermal properties and can be used as a high-temperature PCM for Concentrating Solar Power (CSP) applications (Jiang et al., 2016). On the basis of the XRF characterization findings for the three samples, it can be inferred that the heat treatment of local salt does not affect the salt consistency as a PCM candidate. On the basis of the findings of the local salt $\mathrm{NaCl}$ content, which is included in category III, the local Aceh salt is not recommended as a raw material for high-temperature PCM. However, it is recommended for low-temperature PCM (Gunawati et al., 2019a, 2019b).

\section{Morphological and elemental analysis}

Furthermore, the elemental and morphology of local Aceh salts, as well as the findings of SEM analysis of the salt characteristics, were examined by using SEM-EDS.

The SEM analysis findings show that with a magnification of $5000 \mathrm{x}$, it can be seen that the local salt surface is coarse and irregular in structure. Meanwhile, EDS shows the presence of $\mathrm{Na}$ in large quantities. When compared with $\mathrm{XRF}$, there is no visible element of $\mathrm{Na}$ in local

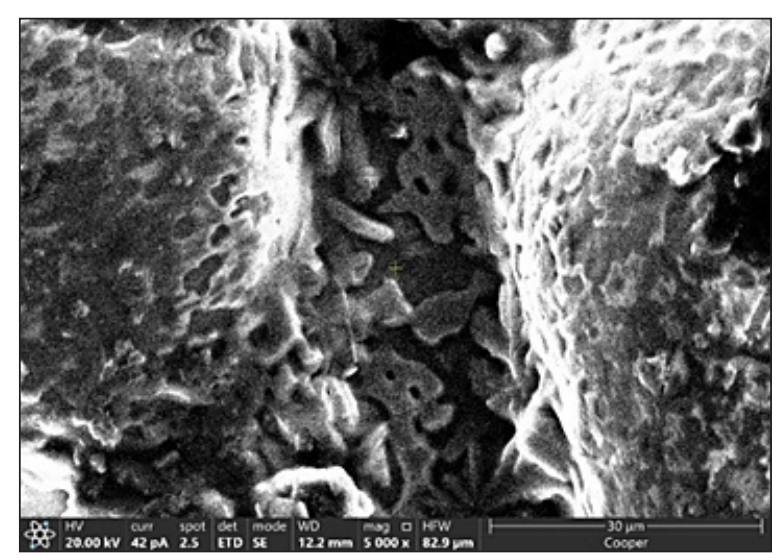

Figure 1. Morphological SEM from Aceh local salt 


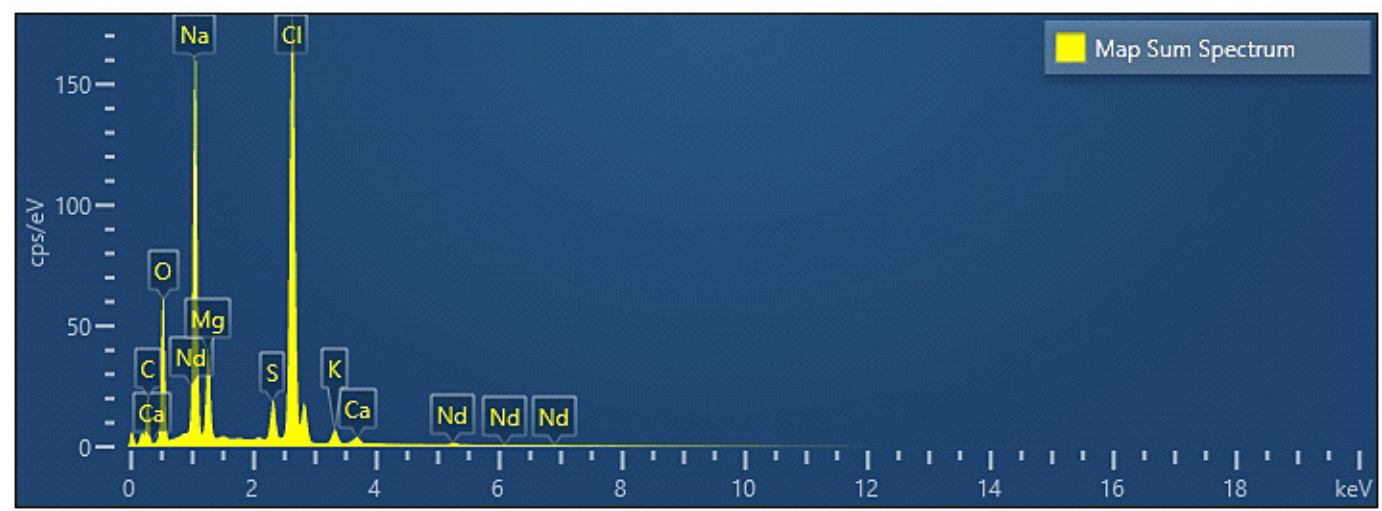

Figure 2. Elemental analysis EDS result from Aceh local salt

salt compounds, but with the SEM-EDS tool, it is clear that there is $\mathrm{Na}$ in a quantity of $12.15 \%$, while other elements, such as $\mathrm{Ca}, \mathrm{S}, \mathrm{Nd}, \mathrm{K}$, are still seen in small numbers. Likewise, elemental oxygen with XRF is not visible, but with SEM, it is seen in amounts that exceed $50 \mathrm{cps} / \mathrm{eV}$.

\section{Crystal size analysis}

Figure 3 shows the emergence of several peaks defined as local salt $(\mathrm{NaCl})$, where the $\mathrm{NaCl}$ compound can be determined by adjusting the XRD result data with the $\mathrm{NaCl}$ database. It can also be seen that there is no change in phase composition (no new phase is formed) of the sample before and after heat treatment. It can be observed from the absence of a significant change in the position of the two theta angles, implying that heat treatment of the $\mathrm{NaCl}$ sample induces a single phase. From the figure, it is also seen that the highest optimum peak results occur at a treatment temperature of $400{ }^{\circ} \mathrm{C}$; thus, it can be said that the $\mathrm{NaCl}$ content is more significant under these conditions.

Furthermore, the crystal size is determined based on the widening of half the diffraction peaks that arise from a material or FWHM. The crystal size produced from local salt $(\mathrm{NaCl})$ with various heat treatment temperatures can be seen in Table 2.

According to Table 2, adding hot temperatures to local salt $(\mathrm{NaCl})$ will influence the size of the material crystal. The greater the temperature difference, the larger the resulting salt crystal size. When a compound is heated, the crystal size expands. It is due to the fact that the higher the sintering temperature applied to the sample, the more energy the atoms gain to diffuse and agglomerate. As a result, the size of the crystals produced on the grain becomes larger, and the bonds between atoms become stronger and more frequent. By the crystal size of the grains, each grain will experience formation, resulting in tighter grains. After heating the sample, the bonds between the powders will be stronger. The increased bonding of the material becomes more compact. In this case, the grain size also affects the compatibility of a material (Callister, 1991).

\section{Thermal analysis}

Thermal analysis of traditional Aceh salt samples was carried out using DSC/TGA under the Mettler Toledo TGA/DSC machine. This analysis

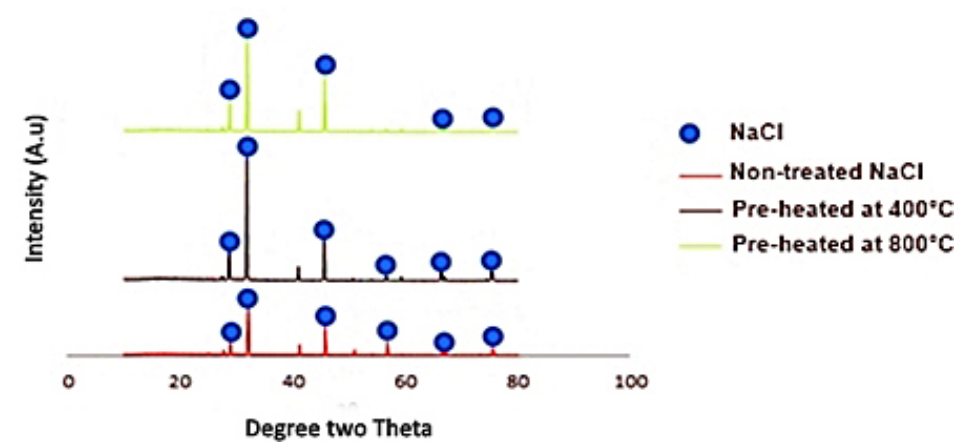

Figure 3. XRD Test results on local salt $(\mathrm{NaCl})$ with heating temperature variations 
Table 2. Crystal sizes of XRD analysis

\begin{tabular}{|c|c|c|c|}
\hline Sample & FWHP & Peak position (degree two theta) & Crystal size $(\mathrm{nm})$ \\
\hline Un-treated $\mathrm{NaCl}$ & 0.2231 & 32.0191 & 39.10 \\
\hline Pre-heated at $400^{\circ} \mathrm{C}$ & 0.1519 & 31.8238 & 57.40 \\
\hline Pre-heated at $800^{\circ} \mathrm{C}$ & 0.1199 & 31.8957 & 72.73 \\
\hline
\end{tabular}

begins with heating the sample from room temperature to $900{ }^{\circ} \mathrm{C}$. Figure 4 shows the weightto-temperature curves of the three sample types.

The three samples in the graph above show that local salt's heat treatment affects the rate of sample weight reduction as the temperature rises to $900{ }^{\circ} \mathrm{C}$; this occurs at temperatures of $0{ }^{\circ} \mathrm{C}$ to $200{ }^{\circ} \mathrm{C}$. The samples heated at $800^{\circ} \mathrm{C}$ were seen to be more stable than the other two samples. The samples heated at $800{ }^{\circ} \mathrm{C}$ exhibited a decrease in sample weight by $0.95 \%$, whereas the samples heated at $400{ }^{\circ} \mathrm{C}$ showed a decrease in sample weight by $1.43 \%$ and the unheated samples had a decreased weight by $3.57 \%$. Furthermore, at a temperature of $200{ }^{\circ} \mathrm{C}$ to $800{ }^{\circ} \mathrm{C}$, the weight loss shows stability, while at temperatures of $800{ }^{\circ} \mathrm{C}$ to $900{ }^{\circ} \mathrm{C}$, decomposition occurs. The results obtained from this study are close to that reported by Alexander et.al. The weight loss rate of $0.9 \%$ is caused by the evaporation of a portion of the sample (Schindler and Schöneich, n.d.).

Figure 5 illustrates the DSC heat flow curves of the salt samples before and after heating. The negative heat flow indicates that the sample emits heat into the atmosphere. This sharp peak reflects the sample's solid-liquid phase transition. The melting temperature of unheated salt samples was $792.56^{\circ} \mathrm{C}$, then the samples heated at $400{ }^{\circ} \mathrm{C}$ were $792.80^{\circ} \mathrm{C}$ and the samples heated at $800{ }^{\circ} \mathrm{C}$ were $792.88{ }^{\circ} \mathrm{C}$. The results obtained from this study are close to the value reported by Alexander et al., with a melting temperature of $802.1^{\circ} \mathrm{C}$ (Schindler and Schöneich, n.d.).

Table 3 summarizes the findings of the characteristic tests of local salt that was given heat treatment or without heat treatment. The findings

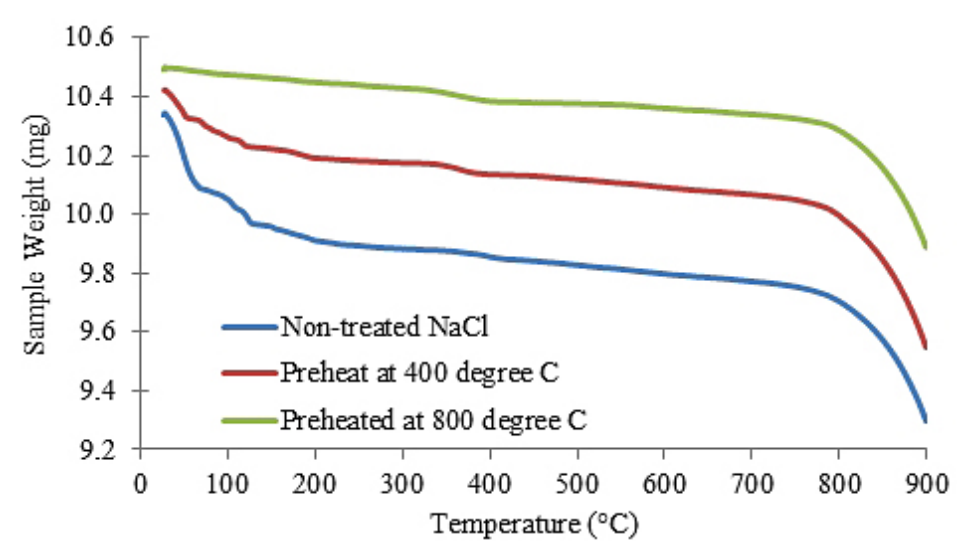

Figure 4. Results of TGA local salt with temperature treatment

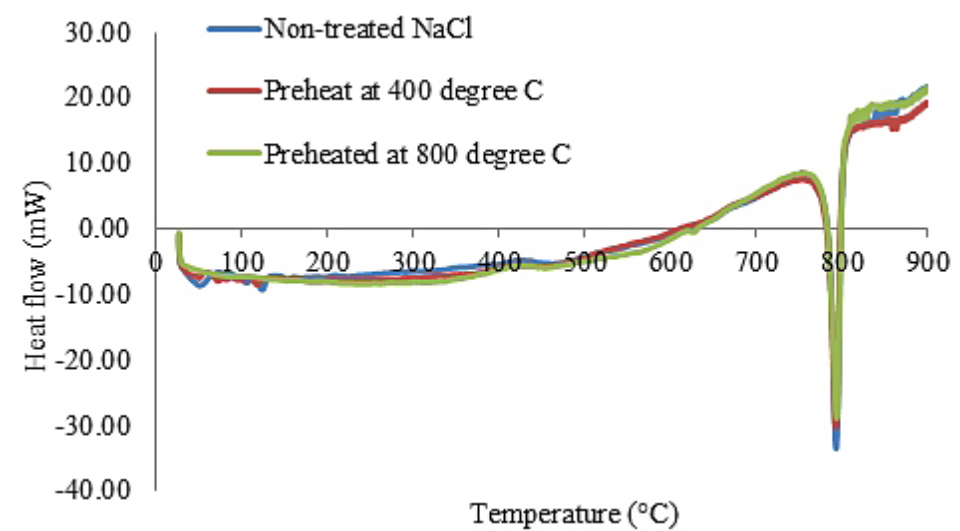

Figure 5. Enlarged DSC graph 2 results 
Table 3. Characteristics of Aceh local salt

\begin{tabular}{|c|c|c|c|c|c|c|}
\hline Samples & $\begin{array}{c}\text { Melting } \\
\text { Temperature } \\
\left({ }^{\circ} \mathrm{C}\right)\end{array}$ & $\begin{array}{c}\text { Melting } \\
\text { enthalpy } \\
(\mathrm{KJ} / \mathrm{kg})\end{array}$ & $\begin{array}{c}\text { Thermal } \\
\text { conductivity } \\
\left(\mathrm{W} / \mathrm{m}^{\circ} \mathrm{C}\right)\end{array}$ & $\begin{array}{c}\text { Crystal size } \\
(\mathrm{nm})\end{array}$ & $\begin{array}{c}\text { Density } \\
\left(\mathrm{gr}^{\circ} / \mathrm{cm}^{3}\right)\end{array}$ & $\begin{array}{c}\text { Average electrolyte } \\
\text { conductivity meter } \\
(\mathrm{ms} / \mathrm{cm})\end{array}$ \\
\hline Un-treated $\mathrm{NaCl}$ & 792.59 & 519.133 & 2.3 & 39.10 & 1.047 & 52.2 \\
\hline Pre-heated at $400^{\circ} \mathrm{C}$ & 792.80 & 558.343 & - & 57.40 & 1.068 & 99.3 \\
\hline Pre-heated at $800^{\circ} \mathrm{C}$ & 792.88 & 622.164 & - & 72.73 & 1.133 & 113.6 \\
\hline
\end{tabular}

are melting temperature and melting enthalpy derived from the TGA/DSC analysis, thermal conductivity derived from the Single Plate Method calculation, and crystal size derived from the XRD analysis. Furthermore, the density calculations using bulk density and electrolyte conductivity are derived from Laboratory Benchtop Meter measurements.

The melting temperature value of the three samples did not change significantly, indicating that heat treatment of local salt had little effect on the melting temperature value. Meanwhile, as the salt is heated to a higher temperature, there is a rise in enthalpy. The same is true for thermal conductivity and electrolyte conductivity. The crystal size and density value also increased with heat treatment, consistent with the effect of particle solidification caused by increased crystal size, which affects the density value.

\section{CONCLUSION}

The salt produced traditionally on the coast of Aceh has been studied for its physical and chemical properties as a candidate material for thermal energy storage. According to this study's findings, the salt can be categorized as grade III $(\mathrm{NaCl}<94 \%)$ and is suitable for use as a thermal energy storage material. In terms of melting temperature, the salt with or without heat treatment is applicable for energy storage. The heat treatment of local salts increases the value of melting enthalpy, melting temperature, crystal size, density and electrolyte conductivity. The best heat treatment method for local Aceh salt is heating it to a temperature of $800{ }^{\circ} \mathrm{C}$ to obtain melting enthalpy and crystal size reaching $622,164 \mathrm{~mW}$ and $72.73 \mathrm{~nm}$.

\section{Acknowledgments}

The author would like to express gratitude to LPPM USK for funding this research activity through contract No.182/UN11.2.1/PT.01.03/
PNBP/2020. The authors also thank Dr. Ismail, Dr. Suhrawardi Ilyas, Dr. Martha Riana who took part in the study and writing articles.

\section{REFERENCES}

1. Agyenim F., Hewitt N., Eames P., Smyth M. 2010. A review of materials, heat transfer and phase change problem formulation for latent heat thermal energy storage systems (LHTESS). Renewable and Sustainable Energy Reviews, 14, 615-628. https://doi. org/10.1016/j.rser.2009.10.015

2. Anand A., Shukla A., Sharma A. 2020. Thermal Energy Storage Using Phase Change Materials: An Overview, Latent Heat-Based Thermal Energy Storage Systems. https://doi. org/10.1201/9780429328640-1

3. Callister W.D. 1991. Materials science and engineering: An introduction (2nd edition). Materials \& Design, 12, 59. https://doi.org/10.1016/0261-3 069(91)90101-9

4. Gunawati, Dongoran A.H., Setiawan A. 2019a. Evaluation on performance of cold storage box enveloped with phase change materials. Journal of Physics: Conference Series, 1242. https://doi.org/1 0.1088/1742-6596/1242/1/012023

5. Gunawati, Noor N., Sebayang K., Setiawan A. 2019b. Experimental investigation of a cold storage box with Aceh locally produced hydrated salt as phase change materials: Effect of salt treatment. IOP Conference Series: Earth and Environmental Science, 364. https://doi.org/10.1088/1755-1315/ 364/1/012019

6. Mehling H., Cabeza L.F. 2000. Heat and cold storage with PCM, Journal of Visual Languages \& Computing.

7. Jegadheeswaran S., Pohekar S.D. 2009. Performance enhancement in latent heat thermal storage system: A review. Renewable and Sustainable Energy Reviews, 13, 2225-2244. https://doi. org/10.1016/j.rser.2009.06.024

8. Jiang Y., Sun Y., Liu M., Bruno F., Li S. 2016. Eutectic $\mathrm{Na} 2 \mathrm{CO} 3-\mathrm{NaCl}$ salt: A new phase change material for high temperature thermal storage. Solar Energy Materials and Solar Cells, 152, 155-160. https://doi. org/10.1016/j.solmat.2016.04.002 
9. Mehling H., Cabeza F. 2008. Heat and Cold Storage with PCM: An Up to Date Introduction Into Basic and Aplications. Springer, Berlin.

10. Myers P.D., Goswami D.Y. 2016. Thermal energy storage using chloride salts and their eutectics. Applied Thermal Engineering, 109, 889-900. https:// doi.org/10.1016/j.applthermaleng.2016.07.046

11. Nazir H., Batool M., Bolivar Osorio F.J., Isaza-Ruiz M., Xu X., Vignarooban K., Phelan P., Inamuddin, Kannan A.M. 2019. Recent developments in phase change materials for energy storage applications: A review. International Journal of Heat and Mass Transfer, 129, 491-523. https://doi.org/10.1016/j. ijheatmasstransfer.2018.09.126

12. Salim Z., Munadi E. 2016. Info Komoditi Garam, Al Mawardi Prima.

13. Schindler A., Schöneich M., n.d. Investigation of
Alkali Salts, 1-5.

14. Sharma A., Tyagi V.V., Chen C.R., Buddhi D. 2009. Review on thermal energy storage with phase change materials and applications. Renewable and Sustainable Energy Reviews, 13, 318-345. https:// doi.org/10.1016/j.rser.2007.10.005

15. Strizhenok A.V., Ivanov A.V. 2021. Monitoring of Air Pollution in the Area Affected by the Storage of Primary Oil Refining Waste, 22, 60-67.

16. Tian H., Du L., Huang C., Wei X., Wang W., Ding J. 2017. Enhanced Specific Heat of Chloride Salt with Mg Particles for High-temperature Thermal Energy Storage. Energy Procedia, 105, 4402-4407. https:// doi.org/10.1016/j.egypro.2017.03.934

17. Yalçin Ş., Mutlu İ.H. 2012. Structural Characterization of Some Table Salt Samples by XRD, ICP, FTIR and XRF Techniques, 121, 1-3. 